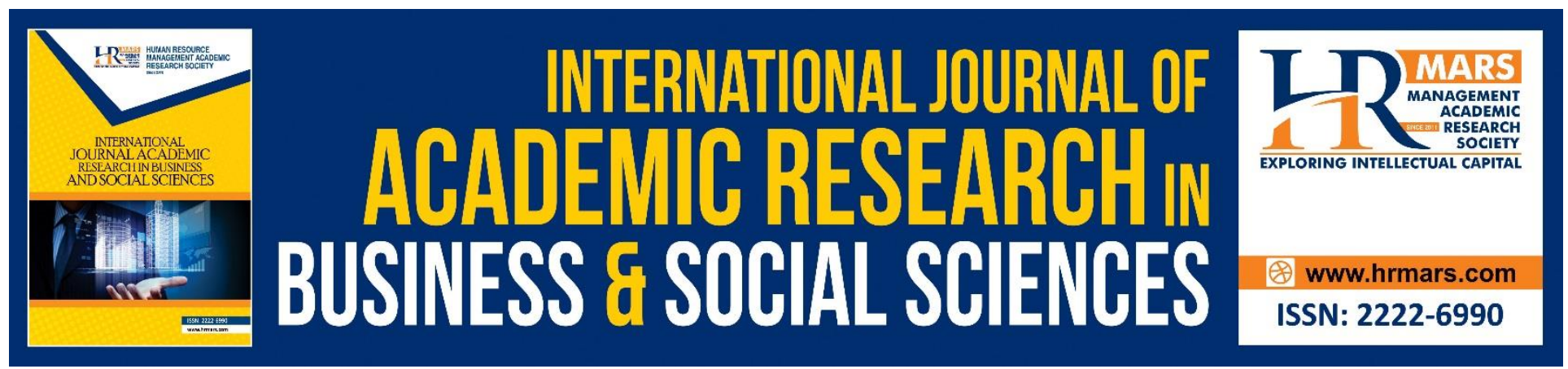

\title{
The Invention of Kuda Pasu as Performing Arts-Dance among the Bajau-Sama in Kota Belud, Sabah.
}

Abdul Hamid Chan, Muhammad Fazli Taib Saearani

To Link this Article: http://dx.doi.org/10.6007/IJARBSS/v10-i7/7431

DOI:10.6007/IJARBSS/v10-i7/7431

Received: 02 April 2020, Revised: 08 May 2020, Accepted: 19 June 2020

Published Online: 29 July 2020

In-Text Citation: (Chan, 2020)

To Cite this Article: Chan, A. H. M. F. T. S. (2020). The Invention of Kuda Pasu as Performing Arts-Dance among the Bajau-Sama in Kota Belud, Sabah. International Journal of Academic Research in Business and Social Sciences, 10(7), 406-412.

Copyright: (c) 2020 The Author(s)

Published by Human Resource Management Academic Research Society (www.hrmars.com)

This article is published under the Creative Commons Attribution (CC BY 4.0) license. Anyone may reproduce, distribute, translate and create derivative works of this article (for both commercial and non-commercial purposes), subject to full attribution to the original publication and authors. The full terms of this license may be seen at: http://creativecommons.org/licences/by/4.0/legalcode

Vol. 10, No. 7, 2020, Pg. 406 - 412

http://hrmars.com/index.php/pages/detail/IJARBSS

JOURNAL HOMEPAGE

Full Terms \& Conditions of access and use can be found at http://hrmars.com/index.php/pages/detail/publication-ethics 


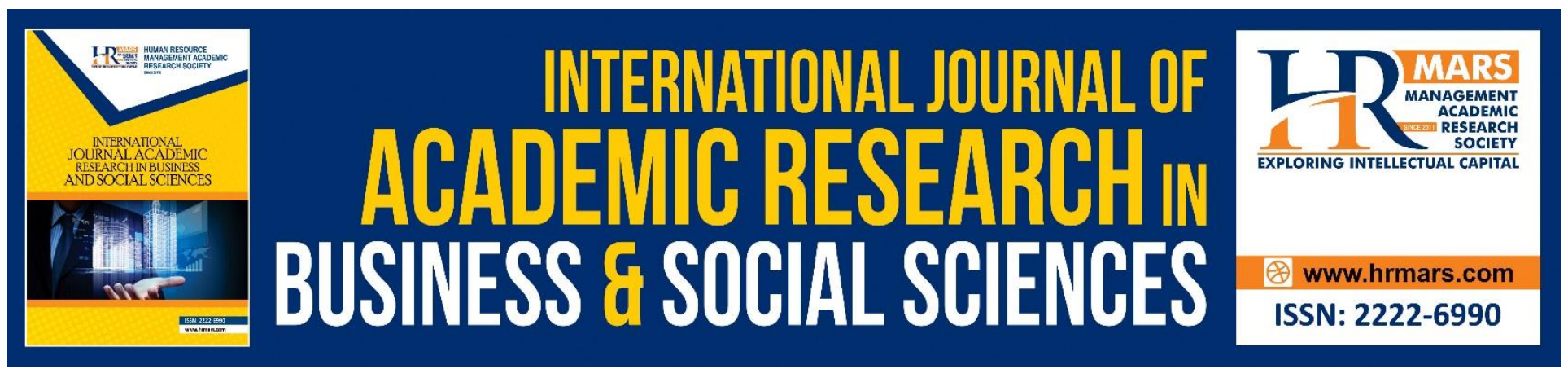

\title{
The Invention of Kuda Pasu as Performing Arts- Dance among the Bajau-Sama in Kota Belud, Sabah.
}

\author{
Abdul Hamid Chan, Muhammad Fazli Taib Saearani \\ Sultan Idris Education University, Malaysia \\ Email: hamid.chan@fmsp.upsi.edu.my, fazli@fmsp.upsi.edu.my
}

\begin{abstract}
This paper discusses on the invention of Kuda Pasu as an art of dance of Bajau-Sama society in Kota Belud, Sabah. Kuda Pasu was first introduced as a traditional dance on the stage of Tamu Besar Kota Belud in 1976. Besides portraying form of dance movements, Kuda Pasu becomes the reflection of the lifestyle of Bajau-Sama society in Kota Belud, particularly male. In current development, Kuda Pasu has been highlighted as one of Sabah traditional dances. This paper highlights the survival issue of Kuda Pasu, if the art form still remains as it was in introductory form in 1976, and if Kuda Pasu still dances as an art of dance in Kota Belud. Using Eric Hobsbawm and Terence Ranger's Invention, as well as Edward Shil's Tradition, this paper investigates Kuda Pasu as an art of dance that practiced merely to meet the current demand.
\end{abstract}

Keywords: Invention, Tradition, Kuda Pasu.

\section{Introduction}

Hobsbawm \& Ranger (1983), stated that an invention is when a tradition is revived and recreated according to the beholder's culture and tradition requirements. Shils (1981) describes that the relationship of traditions and local community is passed down over generations, whether a new creation by the beholder or modification by external influences will remain as a tradition. Kuda Pasu is a dance created by Jeffry bin Oleh in 1976. According to Jeffry, the creation of Kuda Pasu in that year was intended to be contested in Sabah Traditional Dance Competition held during Tamu Besar Kota Belud (Oleh, 2009). Prior to that, Kuda Pasu has been around since the year 1974, known as the Main Kuda Pacu. Main Kuda Pacu is a folk game-play played by children or young men at wedding festivities or any events held among Bajau community in Kota Belud. This game-play portrays and imitate the movements of a rider riding a horse.

At present, Main Kuda Pacu may not sustained itself as a game-play performance amongst the Bajau in Kota Belud, however it has continued today as an invented dance tradition known as Kuda Pasu. Jeffry bin Oleh has created a structured movements system inspired from Main Kuda Pacu that shows sturdy and strong shape and leg structure (Oleh, 2009). According to Jeffry, the creation of Kuda Pasu dance was not only a performing arts, but it mirrors the equestrian lives of men in Kota Belud Bajau. 
INTERNATIONAL JOURNAL OF ACADEMIC RESEARCH IN BUSINESS AND SOCIAL SCIENCES Vol. 10, No. 7, July, 2020, E-ISSN: 2222-6990 @ 2020 HRMARS

\section{The Emergence of Kuda Pasu in Kota Belud (1974 - 1976)}

In 1976, the Kuda Pasu dance emerged in Kota Belud as an invented dance choreographed by Jeffry bin Oleh, a native-born Bajau of Kampung Kota Belud. He inherited his skill and knowledge of martial arts and performing arts from his family. He himself dance and play the Kulintangan music ensemble and play music repertoires in Bertitik. When he was young, he often play Main Kuda Pacu at events such as weddings, usually accompanied by Tigad-Tigad music repertoire. He learned to play all kinds of music repertoires from his teacher Piluk Bte Maidan, a skilled Kulintangan musician in Kota Belud.

Basically, Main Kuda Pacu is played spontaneously when the Tigad-tigad song being played. As Jeffry is skilled in martial arts, he emphasized on leg movements to demonstrate the strength of the leg structure. Hands movements however, is quite limited.

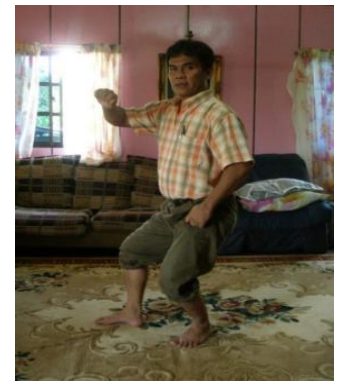

Photo 1: Sila-Sila

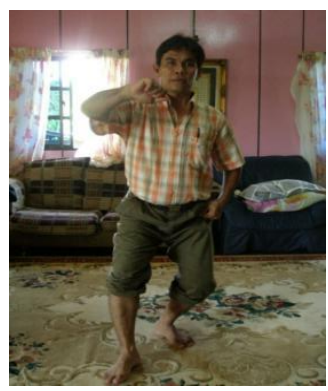

Photo 2: Totok

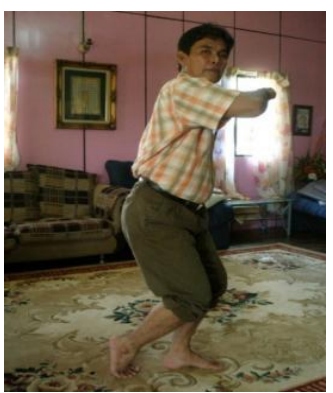

Photo 3: Pacu

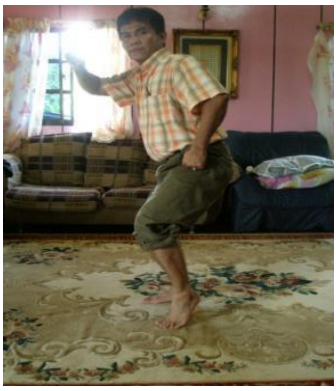

Photo 4: Pacu-Pacu

(Source: Abdul Hamid Chan, 2009)

\section{Structure and Style of Kuda Pacu}

Kaeppler (1999) stated that the structural elements determines how a dance is formed. The flow and style are differentiated through how someone presents it and realizing the structure. Kaeppler also noted that, style refers to a form or continuous pattern in the manner of expressing the movement quality. Kuda Pacu movement structure is divided into two part, the lower part of the body and the upper body part from waist to top. Kuda Pacu movement structure by Jeffry emphasises on the lower part of the body especially on both feet, while the movement of the upper body is very limited.

At its early appearance, Kuda Pacu was categorized as a consistent dance form. This is mainly because, almost every performance was under Jeffry's supervision through Kumpulan Anak-Anak Seni Bajau Kota Belud - KASBKB (Bajau's Children Arts Association of Kota Belud), where he acted as choreographer and advisor to the troupe. However, changes in the structure and style in Kuda Pacu takes place when the dance was taken out of the Kota Belud.

\section{Kuda Pacu in Kota Kinabalu (1977-1989)}

Ever since Kuda Pacu dance piece choreographed by Jeffry wins the Sabah Traditional Dance Competition in 1976, it was then brought out of the Kota Belud and presented for the first time in 1977 before the Tuan Yang DiPertua Negeri Sabah, (TYT). According to Jeffry, Kuda Pacu at that time still retains the original movement structure as performed by KASBKB dancers. Later in 1978, the 
INTERNATIONAL JOURNAL OF ACADEMIC RESEARCH IN BUSINESS AND SOCIAL SCIENCES Vol. 10, No. 7, July, 2020, E-ISSN: 2222-6990 @ 2020 HRMARS

group had to merge under the patronage of Persatuan Kebudayaan Sabah (Sabah Cultural Association). However, KASBKB association faced several internal difficulties and finally halted, and later relocated under the supervision of Lembaga Sukan Dan Kebudayaan Sabah (Sabah Sports and Cultural Board), Ministry of Culture, Youth and Sports Sabah (MCYS). In 1996, MCYS has been split into two separate entities, namely, Lembaga Sukan Negeri Sabah (LSNS) and Lembaga Kebudayaan Negeri Sabah (LKNS).

Changes in different patronage have made Kuda Pacu underwent several rearrangement by number of choreographers. As Jeffry has noted, there were many changes in dance movement creating new variants and versions of Kuda Pacu performance in Kota Kinabalu after he left his career as dancer and choreographer. This can be seen if one view and differentiate between the present and the old Kuda Pacu.

\section{New Variants in Kuda Pasu Dance Structures}

For the purpose of this study, various sources of information have been gathered from individuals, groups, coaches, dancers, and peers of Jeffry bin Oleh to look on how new variants exist in the structure of Kuda Pasu. Anya Peterson Royce stated that there are three possibilities that allow changes in dance; (1) flaws in oral transmission and learning process through imitation leading to innovations from one performance to another (2) adaptation from selected external influences or elements and combination of movement that has similarities and peculiarities, and (3) awareness for revival, re-creation and re-orientation of its original form. The new Kuda Pasu movement structure today emerged as a result of time, lacking of literary and documentation within the community, as well as intercultural encounter that led to the change.

\begin{tabular}{|c|c|l|}
\hline Variant & $\begin{array}{c}\text { Leg } \\
\text { Movements }\end{array}$ & Descriptions \\
\hline 1. & $\begin{array}{c}\text { Henjut } \\
\text { Setempat }\end{array}$ & Bouncing in place \\
\hline 2. & $\begin{array}{c}\text { Bergerak } \\
\text { Jalan }\end{array}$ & Basic leg movements in space \\
\hline 3. & Jaga-Jaga & Leg movements of Bajau's warrior \\
\hline 4. & Lompat Kuda & Horse jump \\
\hline 5. & Lompat Kecil & Small jump \\
\hline
\end{tabular}

Figure: New variations in Kuda Pasu Dance Movements

These new variations not only involved leg movements, but also include hand movements. However, the hands movements do not have specific terms or names. 
INTERNATIONAL JOURNAL OF ACADEMIC RESEARCH IN BUSINESS AND SOCIAL SCIENCES Vol. 10, No. 7, July, 2020, E-ISSN: 2222-6990 @ 2020 HRMARS

\begin{tabular}{|c|c|}
\hline Movement Structure in Kota Kinabalu & Movement Structure in Kota Belud \\
\hline 1. Gerak Enjut Setempat & 1. Gerak Sila-Sila \\
\hline 2. Gerak Jaga-Jaga & 2. Gerak Totok \\
\hline 3. Gerak Lompat Kuda & 3. Gerak Pacu-Pacu \\
\hline 4. Gerak Lompat Kecil & \\
\hline 5. Gerak Buka Silat & \\
\hline
\end{tabular}

Figure: Variations of Kuda Pasu Dance Movements in Kota Kinabalu \& Kota Belud (Source: Abdul Hamid Chan, 2009)

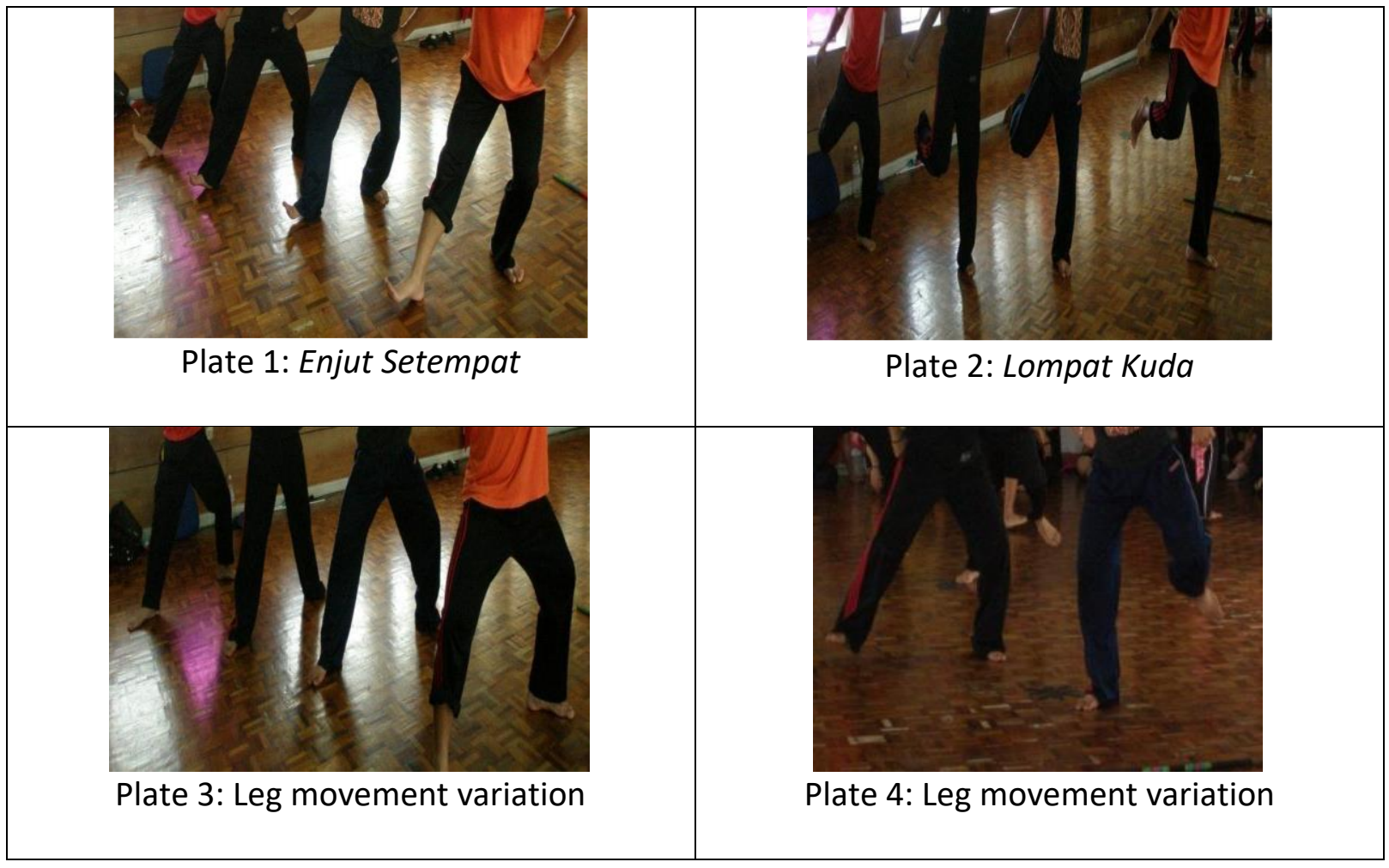

(Source: Abdul Hamid Chan, 2009)

There are also hand movements that were composed together with the leg movement. Hand movements are not just variations of the movement's structure on the Kuda Pasu, but each new movement has created new meanings to the Kuda Pasu. 


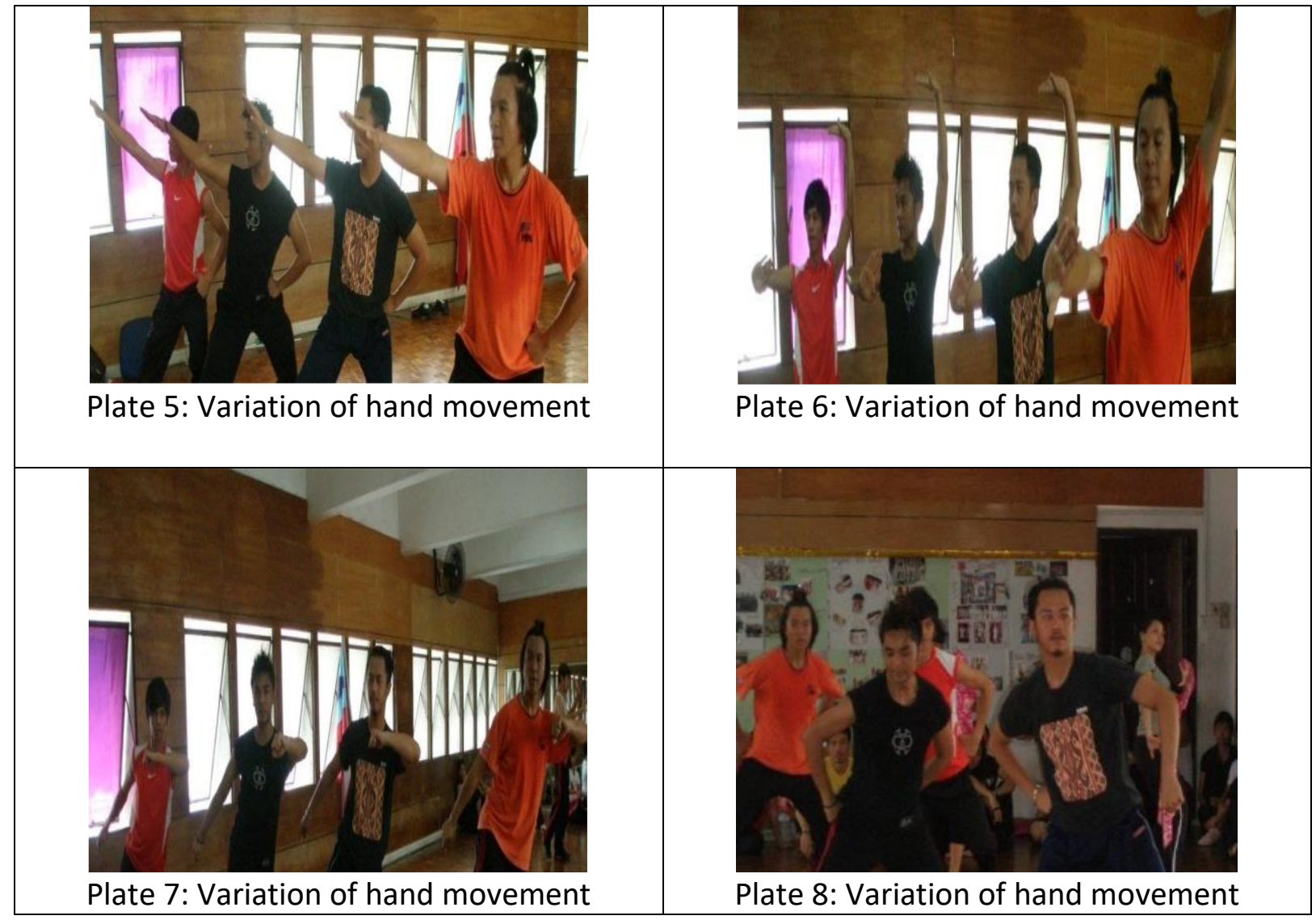

(Source: Abdul Hamid Chan, 2009)

\section{Conclusion}

The development of local and global performing arts have caused many traditional dance performances of the village have gone through transition process via reconstruction for the purpose of stage performances. Kuda Pasu is inseparable from being affected of modernization. As Hobsbawm, E. J., \& Ranger, T. O. (1983).stated, the invention or creation in tradition is a set of new practices adopted by the community. The practice is a new creation for the sake of continuation of tradition from previous generation. Kuda Pasu is indeed an invented dance, but it has survived through several changes regardless of time and space. This occurred as a result of social change, namely when the 'old tradition' disappears, within the period of two century, new invention will emerged among modern or traditional society. The continuity of the 'invented' Kuda Pasu is the will, challenge and individual quest in crafting symbol and identity of Bajau Kota Belud.

Therefore, the sustainability of Kuda Pasu as Kota Belud's Bajau performing art-dance is no longer a 'routine community practice'. Kuda Pasu exist to fulfil present-day demands, influenced by changes in the Kota Belud's Bajau socio-economy, leading to less-interested younger generations who are fascinated with new forms entertainment, media and technology. The society do not practice Kuda Pasu as a traditional performance practice, but the newly invented Kuda Pasu form survived as part of local repertoires perform by arts association and school clubs. 
INTERNATIONAL JOURNAL OF ACADEMIC RESEARCH IN BUSINESS AND SOCIAL SCIENCES

Vol. 10, No. 7, July, 2020, E-ISSN: 2222-6990 @ 2020 HRMARS

\section{References}

Kaeppler, A. L., \& Dunin, E. I. (2007). Dance structures: Perspectives on the analysis of human movement. Budapest: Akadémiai Kiadó.

Kaeppler, A. L. (1999) The Mystique of Fieldwork. In: Buckland T.J. (eds) Dance in the Field. Palgrave Macmillan, London. https://doi.org/10.1057/9780230375291_2

Buckland, T. J. (1999). Dance, Authenticity and Cultural Memory: The Politics of Embodiment. Yearbook of Traditional Music.

San, C. H., \& Fuah, L. A. (2008). The Tamu Sabah's Native Market. Kota Kinabalu: Opus Publication.

Ken, D. W. T. (2004). Historical Sabah: Community and Society. Sabah: Natural History Publication Borneo

Shils, E. (1981). Tradition. Chicago: The University Of Chicago Press.

Hobsbawm, E. J., \& Ranger, T. O. (1983). The invention of tradition. Cambridge, UK ; New York: Cambridge University Press.

Obon, I. (1999). The Sama Horsemen. Sabah: Persatuan Seni Bajau Sabah.

Padasian, J. M. (1988). Sejarah Sabah Dalam Gambar (1881 - 1981), Sabah History in Picture. Sabah: The Sabah centenary Publications Committee.

Getrude, K. (1960). Panorama of Dance Ethnology. Current Anthropology.

Nor, M. A. M. (1986). Randai Dance of Minangkabau Sumatra with Labanotion Scores. Kuala Lumpur: Department of Publications University of Malaya.

Nor, M. A. M. (1993). Zapin: Folk Dance of the Malay World. Singapore: Oxford University Press.

Spencer, P. (1985). Society and the Dance: The Social Anthropology of Process and Performance. London: Cambridge University Press.

Schechner, R. (2005). Performance Theory. New York: Routledge

\section{Interview}

Oleh, J. B. (2009). Personal Interview. 